\title{
Plant nitrogen dynamics in fertilized and natural New England salt marshes: a paired ${ }^{15} \mathrm{~N}$ tracer study
}

\author{
D. C. Drake ${ }^{1,3, *}$, B. J. Peterson ${ }^{1}$, L. A. Deegan ${ }^{1}$, L. A. Harris ${ }^{1}$, E. E. Miller ${ }^{2}$, \\ R. S. Warren ${ }^{2}$ \\ ${ }^{1}$ The Ecosystems Center, Marine Biological Laboratory, 7 MBL Street, Woods Hole, Massachusetts 02543, USA \\ ${ }^{2}$ Connecticut College, Box 5362, New London, Connecticut 06320, USA \\ ${ }^{3}$ Present address: National Institute for Water and Atmospheric Research, 10 Kyle Street, Riccarton, Christchurch, \\ New Zealand
}

\begin{abstract}
We examined the effects of increased nutrient availability on nitrogen (N) dynamics in dominant New England salt marsh plants (tall and stunted Spartina alterniflora and S. patens) using paired large-scale nutrient and ${ }^{15} \mathrm{NO}_{3}{ }^{-}$tracer additions. This study is one component of a long-term, large-scale, salt marsh nutrient and trophic manipulation study (the Trophic Cascades and Interacting Control Processes in a Detritus-based Aquatic Ecosystem [TIDE] Project). We compared physiological variables of plants in fertilized $(\sim 17 \times$ ambient $\mathrm{N}$ and $\mathrm{P}$ in incoming tidal water $)$ and reference marsh systems to quantify $\mathrm{NO}_{3}{ }^{-}$uptake and uptake efficiency, allocation of $\mathrm{N}$ to tissues, end-ofseason $\mathrm{N}$ resorption, leaf litter quality and other potential responses to increased nutrient availability. Reference system plants sequestered $24.5 \mathrm{~g} \mathrm{NO}_{3}-\mathrm{N} \mathrm{ha}^{-1} \mathrm{~d}^{-1}$ in aboveground pools during midsummer, while fertilized plants sequestered $\sim 140 \mathrm{~g} \mathrm{NO}_{3}-\mathrm{N} \mathrm{ha}^{-1} \mathrm{~d}^{-1}$. However, $\mathrm{NO}_{3}{ }^{-}$uptake efficiency (\% of total incoming $\mathrm{NO}_{3}-\mathrm{N}$ sequestered aboveground) was higher in the reference system (16.8\%) than in the fertilized system $(2.6 \%)$, suggesting that our fertilization rate $\left(\sim 70 \mu \mathrm{M} \mathrm{NO}_{3}{ }^{-}\right.$in incoming water) approaches or exceeds the uptake saturation point for this vegetation community. Leaf litter quality was clearly affected by $\mathrm{N}$ availability; $\mathrm{N}$ resorption efficiency was lower in all plants of the fertilized system; senesced leaves from the fertilized creek contained $\sim 43 \%$ (tall S. alterniflora), $23 \%$ (stunted S. alterniflora) and $15 \%$ (S. patens) more N per unit biomass than reference creek leaves.
\end{abstract}

KEY WORDS: Spartina alterniflora · Spartina patens · Plant ecophysiology · Eutrophication · Nitrogen isotopes $\cdot$ Nitrogen cycling $\cdot$ Marsh ecosystem

\section{INTRODUCTION}

Nutrient enrichment of surface waters is increasing with population growth in coastal areas and has stimulated primary production in near-shore waters. The resulting decreased light availability and decay of phytoplankton-derived organic matter have led, in turn, to widespread loss of seagrass beds and episodes of hypoxia in coastal waters (Nixon 1995, Cloern 2001). Eutrophication also causes harmful algal blooms, shifts in food webs, increases in sedimentation and, eventually, changes in biogeochemical cycles and biodiversity (National Research Council 1994). Nitrogen (N) is the nutrient primarily responsible for eutrophication of temperate coastal waters, and the flux of bioactive $\mathrm{N}$ as $\mathrm{NH}_{4}{ }^{+}$and $\mathrm{NO}_{3}{ }^{-}$from New England rivers is currently 5 to 20 times higher than during pre-industrial times (Howarth et al. 1996, Jaworski et al. 1997). Coastal salt marshes are known to play an important role in amelioration of watershed-derived nutrient pollution through several mechanisms. Denitrification (conversion of $\mathrm{NO}_{3}{ }^{-}$into gaseous $\mathrm{N}_{2}$ and $\mathrm{NO}_{2}$ ) is one important $\mathrm{N}$ sink and accounted for removal of 7.25 to $8.52 \mathrm{~g} \mathrm{~N}$ $\mathrm{m}^{-2} \mathrm{yr}^{-1}$ in a Massachusetts marsh (Valiela \& Teal 1979, Kaplan et al. 1997). Additionally, salt marsh vegetation can act as a nutrient sink through generations of plant 
matter (e.g. a net annual belowground production of 700 to $900 \mathrm{~g} \mathrm{C}$ (or about 1 to $2 \mathrm{~g} \mathrm{~N} \mathrm{~m}^{-2}$; Howes et al. 1985) and persistence of plant detritus in accreting marsh sediments $\left(\sim 2.7 \mathrm{~g} \mathrm{~N} \mathrm{~m}^{2} \mathrm{yr}^{-1}\right.$; Valiela \& Teal 1979).

Approximately $63 \%$ of New England salt marshes have persisted through 3 centuries of increasing human pressures (Bromberg \& Bertness 2005), but as nutrient loading continues to increase, salt marsh $\mathrm{N}$ dynamics will eventually change. The level of nutrient increase and the time required to evoke a significant change in salt marsh vegetation is unknown, but Verhoeven et al. (2006) stated 'all ecosystems show a characteristic breakdown (or change to an alternative state) after prolonged high nutrient loading.' Ecosystems can generally withstand and absorb some excess nutrients with only minor effects, but when critical thresholds of nutrient loading are surpassed, nutrient cycling is altered. For example, in some wetlands, chronic high rates of nutrient loading have caused loss of biodiversity, changes in vegetation and changes in denitrification reactions (i.e. a shift toward production of $\mathrm{NO}_{2}$, a greenhouse gas, instead of $\mathrm{N}_{2 i}$ Verhoeven et al. 2006). Analogous state changes induced by increased nutrient load have not yet been observed in the salt marsh vegetation communities of New England, possibly because these ecosystems are primarily structured by physical drivers such as tidal exchange and sedimentation. However, even though New England salt marshes have been relatively resistant to historic increases in nutrient loading, experimental $\mathrm{N}$ additions at higher rates (100 to $500 \mathrm{~g} \mathrm{~N} \mathrm{~m}^{-2} \mathrm{yr}^{-1}$ ) have long been known to stimulate plant growth (Mendelssohn 1979, Valiela 1983).

The existing evidence suggests that current $\mathrm{N}$-loading rates are below critical thresholds for changing salt marsh vegetation community composition in most of New England, and that early responses to increased N availability are physiological in nature (i.e. larger plants). Environmental $\mathrm{N}$ availability affects vegetation characteristics such as the quality, production and turnover of leaves and roots, palatability to herbivores and decomposition of senesced tissues. Vegetation characteristics, in turn, can affect larger-scale ecosystem functions; for example, the decay and fragmentation of marsh plant litter contributes significant quantities of ammonium, dissolved organic $\mathrm{N}$ and particulate $\mathrm{N}$ to coastal waters (Valeila et al. 1978). Changes in plant litter quality may then affect large-scale fluxes of organic matter and nutrients, and, ultimately, the overall metabolism of coastal waters.

Vegetation is important from a biogeochemical perspective because of its role in the storage, cycling and allocation of nutrients. However, the physiological 'decisions' made by marsh plants about nutrient uptake and retention must be dictated by competition with other organisms (especially microbiota) and physical sinks (e.g. sorption) for nutrients, space and light. We postulate that as $\mathrm{N}$ availability increases, $\mathrm{N}$-limited salt marsh plants should decrease their 'effort' in obtaining or retaining $\mathrm{N}$, i.e. more nutrient-stressed plants should remove (resorb) more $\mathrm{N}$ from senescing leaves, and as nutrient availability increases, energetic cost should limit resorption. While evidence of this as a general pattern in trees and forbs is equivocal, graminoids (the vast majority of New England marsh plants) conform more closely to this expectation; a comparative study showed that 9 of 14 graminoid species translocated significantly less $\mathrm{N}$ from leaves during senescence when grown in 'high fertility' environments, and the other 5 species showed no difference between high and low fertility sites (Aerts 1996). Little information is available for $\mathrm{N}$ resorption in salt marsh plants, but one comparison of freshwater marsh grasses showed that Zizaniopsis growing in a high-fertility, hydrologically open ecosystem translocated $\sim 26 \%$ of $\mathrm{N}$ from leaves, while Carex in a low-fertility hydrologically closed system translocated $\sim 59 \%$ of $\mathrm{N}$ from leaves to belowground pools (Hopkinson 1992). Growth chamber experiments also demonstrated decreases in $\mathrm{N}$ uptake efficiency and resorption with increasing nutrient supply in freshwater macrophytes (Shaver \& Melillo 1984). Some early effects of eutrophication, then, may be changes in marsh plant nutrient allocation between tissues, nutrient resorption and resulting litter quality. The responses of tall and stunted Spartina alterniflora (a common salt marsh species in New England) may provide special insight because the distribution of the 2 growth forms within New England salt marshes is linked to $\mathrm{N}$ limitation. Interactions between elevation, drainage and salinity drive gradients in soil chemistry, ultimately affecting the solubility of nutrient ions and root uptake kinetics (Morris 1980, Smart 1980). Tall S. alterniflora (1.5 to $3.0 \mathrm{~m}$ ) grows along creek banks in well-drained, relatively oxic soils with consequently higher $\mathrm{N}$ availability, while stunted $S$. alterniflora $(0.2$ to $0.8 \mathrm{~m})$ grows in areas of poor drainage where accumulation of hydrogen sulfide and salt limit $\mathrm{N}$ uptake (Howes et al. 1981). In one relevant study, low marsh plants resorbed less $\mathrm{N}$ from senescing leaves than high marsh plants (Cartaxana \& Catarino 2002), although this pattern was not attributed to $\mathrm{N}$ availability.

The Trophic Cascades and Interacting Control Processes in a Detritus-based Aquatic Ecosystem (TIDE) Project is a multi-year manipulative experiment conducted at the ecosystem scale (study units of $\sim 12 \mathrm{ha}$ ) in the extensive salt marshes of Plum Island, Massachusetts (Fig. 1). The major goals of the project are to quantify the effects and interactions of increased nutrients $\left(\mathrm{NO}_{3}{ }^{-}+\right.$ $\mathrm{PO}_{4}{ }^{3-}$ ) and reduced abundance of a key fish species on 


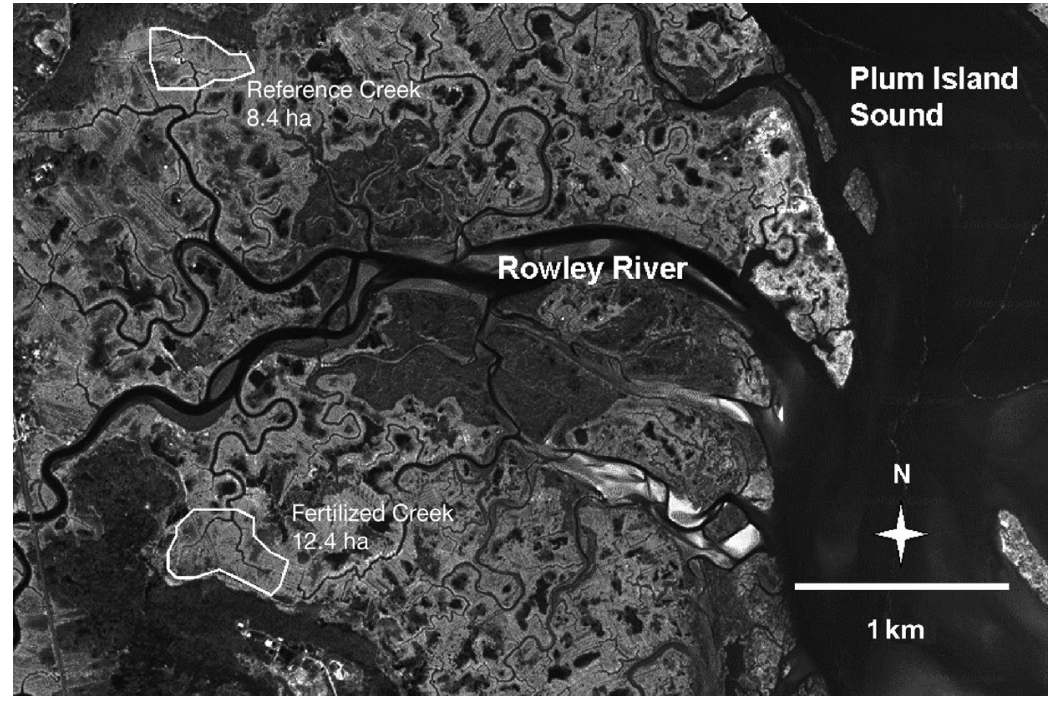

Fig. 1. Satellite photograph (MassGIS Orthophoto 2002) of the Rowley River region salt marshes. Light areas are Spartina patens marsh and the darker areas are $S$. alterniflora marsh. The areas outlined in white are the experimental creeksheds

salt marsh ecosystems. This work focuses on $\mathrm{NO}_{3}{ }^{-}$specifically because increased $\mathrm{NO}_{3}{ }^{-}$export to ground and surface waters is the primary symptom of $\mathrm{N}$ excess (Fenn et al. 1998), and $\mathrm{NO}_{3}{ }^{-}$loading is most closely related to changes in land cover in the local watersheds (Pontius et al. 2000). We present findings from studies of vegetation response and ${ }^{15} \mathrm{~N}$ tracer additions in the second year of experimental surface water fertilization. We examine responses of dominant salt marsh plants to increasing $\mathrm{N}$ availability, addressing 4 basic questions:

(1) How does increasing $\mathrm{NO}_{3}{ }^{-}$availability in surface water affect $\mathrm{N}$ uptake and uptake efficiency in dominant salt marsh macrophytes?

(2) What portion of incoming $\mathrm{NO}_{3}{ }^{-}$in surface water is incorporated into the aboveground standing crop of Spartina alterniflora and S. patens in fertilized and reference salt marshes; do species or phenotypes respond differently to increased $\mathrm{N}$ availability?

(3) Does nutrient enrichment affect $\mathrm{N}$ resorption or resulting litter quality?

(4) Does $\mathrm{N}$ isotope distribution within plants provide evidence of significant foliar $\mathrm{N}$ uptake or for changes in allocation of $\mathrm{N}$ to leaves, roots or rhizomes with increasing $\mathrm{N}$ availability?

\section{MATERIALS AND METHODS}

Study sites. The Plum Island Sound estuary (a National Science Foundation Long-term Ecological Research Site; Fig. 1) in northern Massachusetts, USA, is a relatively pristine salt marsh estuary. Our study sites lie within the Rowley River watershed, which drains an area of approximately $25 \mathrm{~km}^{2}$ and supports a human population of $\sim 5500$. The larger Parker River $\left(200 \mathrm{~km}^{2}\right)$ watershed is $44 \%$ forested, $16.9 \%$ residential, $16.6 \%$ salt marsh and $7.5 \%$ agriculture and pasture. Sewage treatment is primarily through septic systems, and the largest water quality concerns in the watershed are bacteria/pathogens and increasing $\mathrm{N}$ and $\mathrm{P}$ loading attributed to septic systems and agriculture (Commonwealth of Massachusetts 2005).

The West and Sweeney creek study areas (8.4 ha reference and 12.4 ha fertilized systems, respectively) are the tidally flooded area of each creek's watershed influenced by our ${ }^{15} \mathrm{~N}$ additions. The areas were determined and mapped before the experiments by adding a tracer dye to flooding waters at the point of the ${ }^{15} \mathrm{~N}$ addition (Fig. 1); water was collected in narrow-mouth bottles set out in a grid on the marsh surface and fluorometrically tested for presence of the dye (Fluorometer Model 10-AU, Turner Designs). The Sweeney-West pairing was determined in 2003 based on plant communities and position in the estuary. Plant community similarity analyses detected no difference between the 2 creeksheds ( $p=0.195$; ANOSIM, Primer-E; Miller 2006). Tidal amplitude at the point of tracer addition on each creek varied from 2.1 to $3.4 \mathrm{~m}$, and about $80 \%$ of each total marsh area is considered high marsh, existing at or above the mean high water level and inundated only during spring tides or storms. Tall Spartina alterniflora (150 to $300 \mathrm{~cm}$ in height) dominates low marsh areas that receive daily tidal inundation and covers $\sim 2 \%$ of the experimental areas, but accounts for $>15 \%$ of the total plant biomass (Table 1). Spartina patens (20 to $60 \mathrm{~cm}$ in height) is the most abundant plant in the high marsh, covering 52 to $60 \%$ of the experimental areas; stunted S. alterniflora ( 20 to $80 \mathrm{~cm}$ in height) occurs in mixed stands with $S$. patens and also in pure stands in poorly drained areas, covering 20 to $30 \%$ of our experimental areas. Aboveground plant biomass of each Spartina type was determined from stem densities and dry weight measured in August 2004, and expanded by area determined from detailed plant community maps of the study sites to units of grams dry weight ( $g d w)$ $\mathrm{m}^{-2}$ (Miller 2006; Table 1). Belowground biomass was estimated using an allometrically determined ratio of 1:1.6 for summer aboveground : belowground biomass (after Schubauer \& Hopkinson 1984, Niklas 2004). 
Table 1. Spartina spp. Vegetation coverage and biomass in the study systems (Reference: West Creek, 8.4 ha; Fertilized: Sweeney Creek, 12.4 ha) determined in mid-August 2005. The remaining 14 to $25 \%$ of the study areas is covered by unvegetated stream channel $(\sim 2 \%)$, pannes $(\sim 5 \%$, fertilized system only) and less common species not included in the analyses such as Distichlis spicata, Juncus gerardii, Limmonium carolinum, Atriplex patula, Salicornia europaea and Triglochin maritima. Belowground numbers were estimated using a biomass ratio of $1: 1.6$ (Niklas 1994) and percent $\mathrm{N}$ in roots

\begin{tabular}{|c|c|c|c|c|}
\hline & $\begin{array}{c}\text { Tall } S \text {. } \\
\text { alterniflora }\end{array}$ & $\begin{array}{l}\text { Stunted } S \text {. } \\
\text { alterniflora }\end{array}$ & S. patens & Total \\
\hline \multicolumn{5}{|c|}{ Aerial coverage in study areas (\%) } \\
\hline Reference & 2.1 & 26.6 & 59.9 & 88.6 \\
\hline Fertilized & 2.2 & 19.8 & 52.9 & 74.9 \\
\hline \multicolumn{5}{|l|}{ Area (ha) } \\
\hline Reference & 0.17 & 2.13 & 4.80 & 7.10 \\
\hline Fertilized & 0.27 & 2.46 & 6.56 & 9.28 \\
\hline \multicolumn{5}{|c|}{ Aboveground biomass (kg m $\left.{ }^{-2}\right)$} \\
\hline Reference & 5.415 & 0.607 & 0.513 & \\
\hline Fertilized & 4.845 & 0.571 & 0.488 & \\
\hline \multicolumn{5}{|c|}{ Aboveground biomass (kg) } \\
\hline Reference & 6.822 & 10.197 & 25.443 & 42.463 \\
\hline Fertilized & 9.613 & 12.027 & 39.371 & 61.011 \\
\hline \multicolumn{5}{|c|}{ Estimated belowground biomass (kg) } \\
\hline Reference & 10.916 & 16.316 & 40.709 & 67.940 \\
\hline Fertilized & 15.380 & 19.243 & 62.994 & 97.617 \\
\hline \multicolumn{5}{|c|}{ Aboveground N standing stocks (kg, 15 Aug 05) } \\
\hline Reference & 107 & 142 & 322 & 571 \\
\hline Fertilized & 185 & 187 & 476 & 848 \\
\hline \multicolumn{5}{|c|}{ Estimated belowground N standing stocks (kg, 16 Nov 05$)$} \\
\hline Reference & 171 & $227^{\circ}$ & 515 & 913 \\
\hline Fertilized & 296 & 300 & 761 & 1357 \\
\hline
\end{tabular}

Fertilizer and ${ }^{15} \mathrm{~N}$ tracer additions. We added dissolved $\mathrm{NaNO}_{3}$ and $\mathrm{KPO}_{4}$ to all incoming tidal waters of Sweeney Creek (henceforth the fertilized creek) to mimic surface water nutrient pollution of marsh ecosystems; nutrients dissolved in flooding waters create a gradient of nutrient loading across the marsh proportional to inundation time and frequency. Nutrient solution was pumped from a $1900 \mathrm{l}$ tank into the channel at the study site seaward boundary on all incoming tides from 15 May to 30 September in 2004 and 2005. The nutrient solution addition rate was regulated to match water flux and maintain a relatively constant enrichment; $\mathrm{NO}_{3}{ }^{-}$concentration was increased from $\sim 4 \mu \mathrm{M}$ (background) to $\sim 70 \mu \mathrm{M}$, and $\mathrm{PO}_{4}{ }^{3-}$ was increased from $\sim 1 \mu \mathrm{M}$ (background) to $\sim 5 \mu \mathrm{M}$. Fertil- izer $\delta^{15} \mathrm{~N}$ was $0.7 \pm 0.15 \%$. Methods for the larger TIDE project are described in detail in a summary paper (Deegan et al. 2007).

Beginning on 23 July 2005 we added 10 atom\% $\mathrm{K}^{15} \mathrm{NO}_{3}$ tracer to both creeks. We added tracer to the tank of nutrient solution at the fertilized creek, bringing the fertilizer solution $\delta^{15} \mathrm{NO}_{3}^{-}$to $650 \%$. A total of $39.1 \mathrm{~kg}$ of 10 atom $\%{ }^{15} \mathrm{~N} \mathrm{KNO}_{3}$ was pumped into the creek along with the regular dose of fertilizer $(\sim 1800 \mathrm{~kg} \mathrm{NaNO}$ ) over a period of $5 \mathrm{~d}$ (9 tides). Cost of the ${ }^{15} \mathrm{~N}$ tracer prohibited a longer addition in the fertilized creek. In West Creek (henceforth the reference creek) we added $\mathrm{K}^{15} \mathrm{NO}_{3}$ to all incoming tidal waters to match both water flux and changing background $\mathrm{NO}_{3}{ }^{-}$ concentration through the tidal cycle (estimated using previous years data), targeting a $\delta^{15} \mathrm{~N}$ of $1000 \%$. We added a total of $6.88 \mathrm{~kg}$ of 10 atom $\%{ }^{15} \mathrm{~N} \mathrm{KNO}_{3}$ to the reference system over a period of $42 \mathrm{~d}(6 \mathrm{wk})$. The 3 plant types received different exposures to $\mathrm{NO}_{3}{ }^{-}$and the ${ }^{15} \mathrm{~N}$ tracer: tall Spartina alterniflora in the low marsh is inundated by almost every tide, while the marsh platform species (stunted S. alterniflora and S. patens) is flooded less frequently. Vegetation of the fertilized creek was exposed to $70 \mu \mathrm{M} \mathrm{NO}_{3}{ }^{-}$in tidal water, while the reference creek vegetation was exposed to lower but varying $\mathrm{NO}_{3}{ }^{-}$(2 to $\left.20 \mu \mathrm{M}\right)$. The reference creek ${ }^{15} \mathrm{~N}$ addition was longer and more variable in $\delta^{15} \mathrm{~N}$ (due to changing background $\mathrm{NO}_{3}{ }^{-}$concentration) than the addition in the fertilized creek (Table 2).

Sample collection. The plant $\delta^{15} \mathrm{~N}$ analyses discussed here are based on collections from 3 permanent study plots within the tracer addition areas shown on Fig. 1. The permanent study plots were established in 2003 (1 yr before fertilization). Each plot began in the creek channel, was $10 \mathrm{~m}$ wide and extended onto the marsh platform for $50 \mathrm{~m}$. Each plot included tall

Table 2. Spartina spp. Total tracer ${ }^{15} \mathrm{NO}_{3}-\mathrm{N}$ added to each of the study systems and hours of inundation (exposure) for each of the 3 Spartina types calculated using the average elevation of each plant type. The 2 time periods ( $17 \mathrm{~d}$ ending 9 August and 6 wk ending 3 September) correspond to dates of plant sample collections. Tracer was added to the fertilized creek for $5 \mathrm{~d}$ during spring tides (23 to 28 July) and exposure times include only these $5 \mathrm{~d}$, while tracer was added to the reference creek over the entire $17 \mathrm{~d}$ and exposure times include both spring and neap cycles

\begin{tabular}{|c|c|c|c|c|}
\hline & \multirow{2}{*}{$\begin{array}{c}\text { Tracer } \mathrm{N} \text { added } \\
\text { to study area } \\
\left(\mathrm{g} \mathrm{ha} \mathrm{a}^{-1}\right)\end{array}$} & \multicolumn{3}{|c|}{ - Tracer exposure $(\mathrm{h})$} \\
\hline & & $\begin{array}{c}\text { Tall } S . \\
\text { alterniflora }\end{array}$ & $\begin{array}{l}\text { Stunted } S \text {. } \\
\text { alterniflora }\end{array}$ & S. patens \\
\hline \multicolumn{5}{|c|}{23 Jul-9 Aug 2005} \\
\hline Reference & 49 & 148.3 & 53.7 & 49.7 \\
\hline Fertilized & 437 & 48.6 & 30.1 & 28.3 \\
\hline \multicolumn{5}{|c|}{23 Jul-3 Sep 2005} \\
\hline Reference & 961 & 385.3 & 130 & 119.2 \\
\hline Fertilized & 437 & 48.6 & 30.1 & 28.3 \\
\hline
\end{tabular}


Spartina alterniflora along creek banks, and $S$. patens and stunted $S$. alterniflora on the high marsh platform. Specific collection points were haphazardly located within habitats. Stem density (shoots per unit area) was determined in 4 plots haphazardly located within the permanent plots in August of each year.

Samples for shoot percent $\mathrm{N}, \delta^{15} \mathrm{~N}$ and aboveground standing stocks (average height and weight determination) were collected at monthly intervals in May through August in 2003, 2004 and 2005. Shoots ( $\mathrm{n}=25$ for each date and each Spartina type) were cut at the peat surface and refrigerated within $2 \mathrm{~h}$. Each shoot was washed, measured and dried at $80^{\circ} \mathrm{C}$ for at least $24 \mathrm{~h}$, and then ground. Pre-tracer addition root and rhizome samples of all Spartina types were collected in September 2004. Additionally, 10 root in-growth cores ( $\sim 30 \mathrm{~cm}$ diameter and $100 \mathrm{~cm}$ deep) were buried in May of each growing season in tall S. alterniflora habitat on each creek. The cores (containing new growth only) were exhumed in September of the same year and roots and rhizomes were washed, dried, weighed and ground.

Additional above- and belowground plant materials were collected at the end of the 2005 growing season (16 November 2005) and in the following spring (8 May 2006) for examination of seasonal $\mathrm{N}$ dynamics (after the ${ }^{15} \mathrm{~N}$ tracer additions). At least 3 tall Spartina alterniflora, 3 stunted $S$. alterniflora and 15 S. patens stems and roots were collected from each permanent plot. Both senesced leaves and small $(\leq 3 \mathrm{~cm}$ in height) green leaf sprouts were collected in November 2006. Roots and rhizomes of $S$. alterniflora were separated for analysis, but because $S$. patens roots and rhizomes are difficult to distinguish, they were analyzed together.

$\mathbf{N}$ content and isotopic analyses. Plant tissues were composited by plot on each date for percent $\mathrm{N}$ determination (25 plants were combined into 1 sample representing each plot, so 3 composite values for percent $\mathrm{N}$ were determined for each Spartina type on each date). Most plant tissues were composited by site and Spartina type for $\delta^{15} \mathrm{~N}$ determination. For example, each tall $S$. alterniflora sample contained approximately equal weights of tissue from 75 individual plants (in the May to September 2004-2005 samples) or from at least 9 individual plants (in the November 2005 and May 2006 samples). Percent C and N in plant tissue were determined for each plot $(n=6$ samples per species per creek per date) using a PerkinElmer 2400 Series II CHNS/O analyzer (PerkinElmer Life and Analytical Sciences). All $\delta^{15} \mathrm{~N}$ analyses were conducted at the Stable Isotope Laboratory, Marine Biological Laboratory, Woods Hole, Massachusetts. Standard error was $0.1 \%$ on homogeneous international standards and $0.14 \%$ for replicate samples.
Experimental design and quantitative analyses. We used a BACI-type experimental design with paired experimental units to minimize variability that contributes to error in completely randomized designs (Underwood 1994). Replication of ecosystem-scale experiments is difficult because ecosystems are usually complex, non-random, non-normal and generally violate traditional statistical assumptions (see Maio \& Carstenn 2006) and, therefore, rarely qualify as true replicates. The matched-pair approach helps ameliorate this difficulty. Additionally, the use of large experimental units (in our case 8.4 and 12.4 ha) is both labor-intensive and expensive ( US $\$ 43000$ for the ${ }^{15} \mathrm{NO}_{3}{ }^{-}$tracer alone). However, although subject to the limitations of pseudoreplication (Hurlbert 1984), large-scale manipulative studies such as TIDE provide a truly realistic environment for examining effects and processes at an ecosystem scale; our results include the effects of spatial variation and complexity, interactions between all of the species in the system, gradients across large areas and large habitat patches. Despite their limitations, large-scale studies such as TIDE add valuable new perspectives to existing knowledge derived from traditional, smallscale replicated experiments.

Tracer and total $\mathrm{NO}_{3}^{-}$uptake. A study-specific threshold of significant change in plant tissue $\delta^{15} \mathrm{~N}$ was determined as the average SD of uncomposited samples (9 sets, 3 individual plants of each Spartina type before ${ }^{15} \mathrm{~N}$ tracer addition). The threshold value is $0.48 \%$ (range of 0.09 to $0.86 \%$ ); . we consider any change in $\delta^{15} \mathrm{~N}$ greater than $0.48 \%$ o to be significant. Excess ${ }^{15} \mathrm{~N}$ was determined using values measured $3 \mathrm{~d}$ before the start of the addition because variation in leaf $\delta^{15} \mathrm{~N}$ between the same month in 2004 and 2005 was higher than month-to-month variation in 2004 .

Uptake of $\mathrm{NO}_{3}{ }^{-}$into each pool (e.g. aboveground tall Spartina alterniflora in the fertilized creek) was calculated by expanding the increase in ${ }^{15} \mathrm{~N}$ abundance to total $\mathrm{NO}_{3}{ }^{-}$uptake (Eq. 1). Per mille excess ${ }^{15} \mathrm{~N}$ over the pre-experimental baseline was multiplied by natural abundance of ${ }^{15} \mathrm{~N}$, converted to percent (multiplied by $3.336 \times 10^{-6}$ ), multiplied by 10 to account for the percent ${ }^{15} \mathrm{~N}$ in the tracer (10 atom $\left.\%{ }^{15} \mathrm{~N}\right)$ and multiplied by the $\mathrm{N}$ standing stock of the pool (from Table 1):

$$
\begin{gathered}
\mathrm{NO}_{3}{ }^{-} \text {uptake }(\mathrm{kg})=\text { excess }{ }^{15} \mathrm{~N}_{\text {pool }} \times\left(3.663 \times 10^{-6}\right) \\
\times 10 \times \mathrm{N} \text { standing stock pool }(\mathrm{kg})
\end{gathered}
$$

Uptake efficiency (\%) was simply calculated by dividing the mass of $\mathrm{NO}_{3}{ }^{-}$incorporated into a pool (from Eq. 1) by the total mass of $\mathrm{NO}_{3}{ }^{-}$entering the study system during the period:

Uptake efficiency $=\mathrm{NO}_{3}{ }^{-}$uptake $(\mathrm{kg}) / \mathrm{NO}_{3}{ }^{-}$load $(\mathrm{kg})$ 
$\mathrm{NO}_{3}{ }^{-}$uptake response. $\mathrm{NO}_{3}{ }^{-}$uptake rates $\left(\mu \mathrm{g} \mathrm{N} \mathrm{g}{ }^{-1}\right.$ dry weight of Spartina $\mathrm{h}^{-1}$ ) were calculated by standardizing values from Eq. (1) to inundation times and estimates of belowground (root uptake) or above- and belowground (root plus foliar uptake) biomass. Inundation times were estimated using TideMiner 3.0 software from light detection and ranging (LIDAR) elevation data available from the Plum Island Sound long-term ecological research (http://ecosystems.mbl. edu/pie/) and known tidal heights (NOAA). Using ESRI (Environmental Systems Research Institute) ArcGIS software, elevations were selected from areas supporting each of the 3 Spartina types based on plant distribution maps (Miller 2006). Uptake rates in the reference and fertilized creek were compared by calculating a slope relating loading rate to uptake rate. Although only 2 points are available for each plant type in each system, the points are representative of many composited samples and provide a simple way to compare responses of the 3 Spartina types. Standard deviations were calculated for each species using the percent $\mathrm{N}$ samples described previously.

Nutrient resorption efficiency and proficiency. Leaf nutrient resorption efficiency (NRE) was calculated as the relative difference between mean percent $\mathrm{N}$ of green leaf tissues in mid-August, and percent $\mathrm{N}$ of senesced leaves in mid-November 2005:

$$
\mathrm{NRE}=\left(\% \mathrm{~N}_{\text {green }}-\% \mathrm{~N}_{\text {senesced }}\right) / \% \mathrm{~N}_{\text {green }}
$$

The NRE calculations are based on nutrients per unit leaf mass and do not account for loss of leaf mass during senescence. Errors associated with estimates based on percent $\mathrm{N}$, however, are thought to be relatively small (Aerts 1996), and the most meaningful comparisons here are of $\mathrm{N}$ content in plants of the fertilized versus reference systems and tall versus stunted Spartina alterniflora. Error should be similar between groups.

Nitrogen resorption proficiency (NRP) rankings provide a broader perspective on salt marsh plant $\mathrm{N}$ dynamics. We use a system developed by Killingbeck (1996) in which senesced leaves containing $>1 \% \mathrm{~N}$ indicate a low rate of resorption (low proficiency) and senesced leaves containing $<0.7 \% \mathrm{~N}$ indicate a high rate of resorption (high proficiency). We use Killingbeck's (1996) general guidelines even though they are based on deciduous trees and shrubs because no such measure has been developed specifically for graminoids, and deciduous trees and marsh grasses are comparable in that both are long-lived perennials and average $\mathrm{N}$ resorption across many genera is similar; e.g. $54 \pm 16$ and $58 \pm 14 \%$, respectively (Aerts 1996). Resorption rates for perennial grasses and deciduous trees are 8 to $35 \%$ higher than all other plant genera studied.
Leaching of nutrients from plants may lead to overestimation of resorption and was not measured here. Another study showed $0.7 \mathrm{~g} \mathrm{~m}^{-2} \mathrm{yr}^{-1}$, or $\sim 2 \%$ of total aboveground $\mathrm{N}$ leached from Spartina alterniflora leaves annually (Hopkinson \& Schubauer 1984). Our analyses are based on site-to-site comparisons, which should at least partially control for losses due to leaching.

We used Excel software (Version 9.0.6926 SP-3, Microsoft) to calculate all SD values, and SPSS software (Version 14.0, SPSS) to calculate ANOVAs comparing leaf $\mathrm{N}$ content ( $\mathrm{n}=3$ for each site, species and date $\alpha=0.05$ ), and to calculate slopes for uptake rate comparisons. Changes in $\delta^{15} \mathrm{~N}$ over time were not analyzed using traditional statistical approaches, but were compared with the $0.48 \%$ o threshold value determined specifically for this study.

\section{RESULTS}

\section{Patterns in pre-experimental plant $\delta^{15} \mathrm{~N}$}

Seasonal changes in plant $\delta^{15} \mathrm{~N}$ were examined to determine appropriate baseline values and identify seasonal patterns in plant $\delta^{15} \mathrm{~N}$ that may suggest $\mathrm{N}$ cycling differences attributable to the fertilization initiated in 2004. Leaf $\delta^{15} \mathrm{~N}$ in the fertilized creek did not vary significantly in 2004 (the season before the ${ }^{15} \mathrm{~N}$ addition; Fig. 2, Table 3). In contrast, all 3 Spartina types in the reference system exhibited small but significant $\left(>0.48 \%\right.$ ) variability in leaf $\delta^{15} \mathrm{~N}$, although no consistent trends were evident (Fig. 2). In July 2005 (pre-experimental) tall $S$. alterniflora leaf $\delta^{15} \mathrm{~N}$ in the reference creek was $1.6 \%$ lower than the July 2004 value, suggesting that variability between years is higher than variability between months (Fig. 2) and, therefore, that samples collected immediately before the tracer addition provided the best baseline for ${ }^{15} \mathrm{~N}$ based calculations.

\section{Tracer and total $\mathrm{NO}_{3}^{-}$uptake}

Leaf $\delta^{15} \mathrm{~N}$ increased during the tracer addition in every Spartina type and in both creeks, in all cases exceeding the $0.48 \%$ o threshold (Table 4 , Fig. 2). At the reference creek, Spartina leaves were enriched by 2.01 to $5.25 \%$ over baseline (Table 4, Fig. 2) $17 \mathrm{~d}$ after the ${ }^{15} \mathrm{~N}$ additions were initiated. Spartina leaves from the fertilized creek were slightly more enriched, by 2.29 to $5.94 \%$ over baseline, which is notable because the fertilized system was exposed to the tracer for a shorter period (Table 2). The rates of plant sequestration in aboveground vegetation pools of the reference and fertilized systems were $\sim 24.5$ and $\sim 140 \mathrm{~g} \mathrm{NO}_{3}-\mathrm{N} \mathrm{ha}^{-1} \mathrm{~d}^{-1}$, 

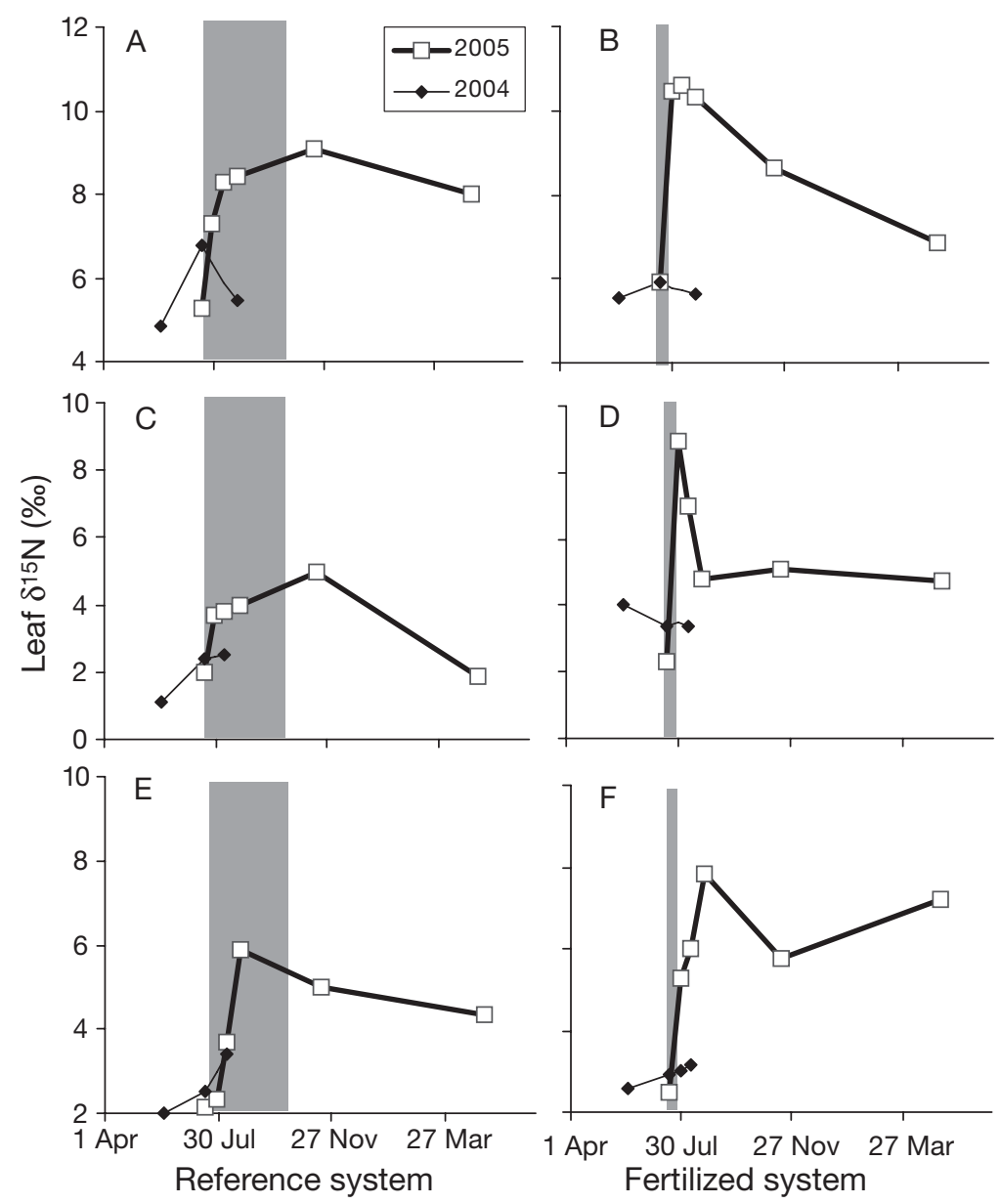

Fig. 2. Spartina spp. Salt marsh plant leaf $\delta^{15} \mathrm{~N}$ over the summer season before ${ }^{15} \mathrm{~N}$ tracer additions showing ranges of seasonal variability (2004) and before, during and after ${ }^{15} \mathrm{~N}$ tracer additions in 2005: $(\mathrm{A}, \mathrm{B})$ tall $S$. alterniflora, $(\mathrm{C}, \mathrm{D})$ stunted $S$. alterniflora, and $(\mathrm{E}, \mathrm{F}) \mathrm{S}$. patens. Although the $\mathrm{N}$ isotope additions (shaded areas) were $6 \mathrm{wk}$ in the reference system and only $5 \mathrm{~d}$ in the fertilized system, the fertilized creek plants consistently became more enriched in tracer $\mathrm{N}$ (had higher maximum $\delta^{15} \mathrm{~N}$ values) during the growing season respectively. These are conservative estimates because they are based on leaf tracer content only (roots were not measured). From a system perspective, the reference creek vegetation took up $\mathrm{NO}_{3}{ }^{-}$ more efficiently from flooding water; reference vegetation sequestered $\sim 16.8 \%$ of the total incoming $\mathrm{NO}_{3}-\mathrm{N}$, while fertilized vegetation sequestered only $\sim 2.6 \%$ (Table 5).

We used leaf $\delta^{15} \mathrm{~N}$ corrected by hours of exposure to flooding tides (Table 2) to estimate minimum $\mathrm{N}$ uptake rates in each of the 3 Spartina types (Fig. 3). We assumed that roots were exposed to concentrations of tracer and total $\mathrm{NO}_{3}{ }^{-}$found in inundating water. Average $\mathrm{NO}_{3}{ }^{-}$was $\sim 7 \mu \mathrm{M}$ in the reference system between 23 July and 8 August, and $90 \mu \mathrm{M}$ in the fertilized system. Concentration-specific uptake rates calculated using kinetic equations developed for tall $S$. alterniflora by Morris (1980) are 0.047 and $0.098 \mathrm{mg} \mathrm{N}$ $\mathrm{gdw}^{-1}$ root $\mathrm{h}^{-1}$ in the reference and fertilized creeks, respectively. Measured uptake rates were consistently higher in the fertilized system compared with those in the reference system, but were considerably lower than the calculated rates of 0.0008 and $0.0026 \mathrm{mg} \mathrm{Ngdw}^{-1}$ root $\mathrm{h}^{-1}$, respectively. Short $S$. alterniflora uptake rates were 0.0013 and $0.0018 \mathrm{mg} \mathrm{N} \mathrm{gdw}^{-1}$ root $\mathrm{h}^{-1}$, and $S$. patens (which were not measured in the Morris [1980] study) measured uptake rates were slightly higher than $S$. alterniflora: 0.0024 and $0.0032 \mathrm{mg}$ $\mathrm{N} \mathrm{gdw}^{-1}$ root $\mathrm{h}^{-1}$ in the reference and fer-

Table 3. Spartina spp. Baseline $\delta^{15} \mathrm{~N}$ in marsh plant tissues from 2004. Leaf $\delta^{15} \mathrm{~N}$ in fertilized system did not change significantly over the season, while small but significant $(>0.48 \%$ ) seasonal changes are seen in all reference system Spartina types. Standard deviations were calculated using the values from the 3 mo ( $=3$ for each SD calculated) and were higher for the reference system in each of the plant types. Roots and rhizomes were combined for analysis of $S$. patens. na = data not available

\begin{tabular}{|c|c|c|c|c|c|}
\hline \multirow{2}{*}{ Creek } & \multicolumn{3}{|c|}{ Leaves } & \multirow{2}{*}{$\begin{array}{c}\text { Roots } \\
15 \text { Sep } 2004\end{array}$} & \multirow{2}{*}{$\begin{array}{r}\text { Rhizomes } \\
15 \text { Sep } 200\end{array}$} \\
\hline & 2 Jun 2004 & 17 Jul 2004 & 24 Aug 2004 & & \\
\hline \multicolumn{6}{|c|}{ Tall S. alterniflora } \\
\hline Reference & 4.86 & 6.80 & 5.47 & 7.13 & 7.12 \\
\hline Fertilized & 5.54 & 5.90 & 5.65 & 5.14 & 6.14 \\
\hline \multicolumn{6}{|c|}{ Stunted $S$. alterniflora } \\
\hline Reference & 1.09 & 2.38 & 2.54 & 3.05 & 3.19 \\
\hline Fertilized & 4.03 & 3.70 & 3.40 & 4.60 & 1.48 \\
\hline \multicolumn{6}{|l|}{ S. patens } \\
\hline Reference & 2.00 & 2.53 & 3.39 & 3.21 & na \\
\hline Fertilized & 2.60 & 2.90 & 3.15 & 2.15 & na \\
\hline
\end{tabular}


Table 4. Spartina spp. Excess ${ }^{15} \mathrm{~N}$ (\%o over baseline) during and after tracer additions. * ${ }^{*}$ designates $\delta^{15} \mathrm{~N}$ values $0.48 \%$ greater or less than baseline, the threshold value determined for this study (i.e. the minimum change in $\delta^{15} \mathrm{~N}$ considered significant here)

\begin{tabular}{|c|c|c|c|c|c|c|}
\hline & \multicolumn{2}{|c|}{9 Aug 2005} & \multicolumn{2}{|c|}{16 Nov 2005} & \multicolumn{2}{|c|}{8 May 2006} \\
\hline & Reference & Fertilized & Reference & Fertilized & Reference & Fertilized \\
\hline \multicolumn{7}{|l|}{ Tall S. alterniflora } \\
\hline Leaf or sprout & $3.05^{*}$ & $4.66^{*}$ & $3.82^{*}$ & $2.71^{*}$ & $2.76^{*}$ & $0.93^{*}$ \\
\hline Dead leaf & & & $2.27^{*}$ & $1.69^{*}$ & & \\
\hline Rhizome & & & $1.39^{*}$ & $1.06^{*}$ & 0.11 & $2.96^{*}$ \\
\hline Root & & & 0.39 & $1.97^{*}$ & -0.40 & $3.45^{*}$ \\
\hline In-growth core rhizome & & & 0.21 & $4.24^{*}$ & & \\
\hline In-growth core root & & & $1.50^{*}$ & $5.05^{*}$ & & \\
\hline \multicolumn{7}{|l|}{ Stunted $S$. alterniflora } \\
\hline Leaf or sprout & $2.01^{*}$ & $2.51^{*}$ & $3.01^{*}$ & $2.79^{*}$ & -0.11 & $2.43^{*}$ \\
\hline Dead leaf & & & $4.68^{*}$ & $4.12^{*}$ & & \\
\hline Rhizome & & & $1.10^{*}$ & -0.53 & $-1.02^{*}$ & $1.09^{*}$ \\
\hline Root & & & 0.40 & $3.30^{*}$ & $-0.77^{*}$ & $2.89^{*}$ \\
\hline \multicolumn{7}{|l|}{ S. patens } \\
\hline Leaf or sprout & $3.75^{*}$ & $5.37^{*}$ & $2.85^{*}$ & $3.26^{*}$ & $2.19^{*}$ & $4.73^{*}$ \\
\hline Dead leaf & & & $4.47^{*}$ & $4.53^{*}$ & & \\
\hline Rhizome + roots & & & $0.68^{*}$ & 0.38 & $1.01^{*}$ & $2.13^{*}$ \\
\hline
\end{tabular}

tilized creeks, respectively. Our measured uptake rates based on ${ }^{15} \mathrm{~N}$ content are lower than those predicted from kinetic equations, at least in part, because they include only leaf biomass.

\section{$\mathrm{NO}_{3}^{-}$uptake response}

We compared uptake rates in the fertilized and reference systems to provide a context for understanding system-scale N-processing. Of the 3 Spartina types, tall $S$. alterniflora responded most strongly to increased $\mathrm{NO}_{3}{ }^{-}$on an aerial basis (reflected in the steepest uptake response, slope $=0.215$ ). Although tall $S$. alterniflora was less enriched in ${ }^{15} \mathrm{~N}$ than $S$. patens (Fig. 2, Table 4), its much larger biomass per unit area $\left(\sim 10 x_{i}\right.$ Table 1$)$ accounts for the higher rate of $N$ sequestration per unit area. Aboveground S. patens

Table 5. Quantity and fate of $\mathrm{NO}_{3}-\mathrm{N}$ entering the reference and fertilized study creeks. SD values in parentheses are based on percent $\mathrm{N}$ measurements

\begin{tabular}{|lcc|}
\hline & $\begin{array}{c}\text { Reference creek } \\
\text { 23 Jul-9 Aug 2005 }\end{array}$ & $\begin{array}{c}\text { Fertilized creek } \\
\text { 23-28 Jul 2005 }\end{array}$ \\
\hline $\mathbf{N O}_{3}$-N influx (kg) & 42.3 & 330.8 \\
Fates (kg) & & \\
Export as unprocessed $\mathrm{NO}_{3}-\mathrm{N}^{1}$ & 0.38 & 150.51 \\
Uptake: & & \\
Tall S. alterniflora & $1.27( \pm 0.20)$ & $1.92( \pm 0.05)$ \\
Stunted $S$. alterniflora & $1.11( \pm 0.07)$ & $1.05( \pm 0.04)$ \\
S. patens & $4.71( \pm 0.56)$ & $5.71( \pm 0.14)$ \\
Aboveground plant total & 7.09 & 8.68 \\
Percent in aboveground plant pools & 16.76 & 2.62 \\
Unprocessed export & 0.90 & 45.50 \\
\hline
\end{tabular}

biomass $\mathrm{m}^{-2}$ was slightly lower than that of stunted $S$. alterniflora (Table 1), but $S$. patens shows an intermediate uptake response to increased $\mathrm{NO}_{3}{ }^{-}$, with a slope approximately $50 \%$ higher than stunted $S$. alterniflora (uptake response slopes $=0.094$ and 0.066 , respectively).

\section{Environmental $\mathbf{N}$ availability versus NRE and NRP}

NRE was significantly higher in the reference system than in the fertilized system for all 3 Spartina types (Table 6). This is consistent with the expectation that the energetic expense of $\mathrm{N}$ resorption should result in decreased 'effort' as environmental $\mathrm{N}$ availability increases. Comparison of NRE in S. alterniflora phenotypes also conforms to these expectations. Stunted plants, which are more strongly N-limited (Morris 1980), have much higher NRE than their tall counterparts in both creeks. Comparison of senesced leaf percent $\mathrm{N}$ and NRP ranking (Table 6) shows convincingly higher $\mathrm{N}$ resorption in all plant types of the reference creek system, and that within each system resorption is highest in stunted $S$. alterniflora. The effect of habitat appears to be stronger than $\mathrm{N}$ availability; stunted $S$. alterniflora in the reference creek resorb the most $\mathrm{N}$ from leaves among the 6 groups of plants, followed by stunted $S$. alterniflora in the fertilized creek. Tall S. alterniflora grows in sediments that are relatively oxic and have high rates of porewater drainage, 
facilitating $\mathrm{N}$ uptake by roots. However, $\mathrm{N}$ resorption in the reference creek tall $S$. alterniflora is still significantly higher than in the fertilized creek. In both creeks, $S$. patens exhibited mid-range $\mathrm{N}$ resorption.

\section{Effects of increased $\mathbf{N}$ loading on $\mathbf{N}$ distribution in plant tissues}

Marsh grass litter quality was clearly changed by the TIDE fertilization experiment. The $\mathrm{N}$ content of senesced leaves in the fertilized system was 43 , 23 and $15 \%$ higher than for leaves in the reference system for tall Spartina alterniflora, stunted $S$. alterniflora and S. patens, respectively (ANOVA: p < 0.01 for differences between creeks, $p<0.001$ for differences between species; interaction was not significant; Table 6).

Roots, rhizomes and leaf sprouts (new leaf growth formed in the late summer that can potentially overwinter) collected after leaf senescence in November show several notable patterns in $\mathrm{N}$ content and $\delta^{15} \mathrm{~N}$. (1) Roots of all plant types at both sites were significantly enriched with tracer $\mathrm{N}$, but were generally less enriched than leaves (Table 4). (2) Roots and rhizomes, like leaves, were consistently more enriched in the fertilized system. (3) Fertilized tall Spartina alterniflora roots and rhizomes and stunted $S$. alterniflora rhizomes had significantly higher percent $\mathrm{N}$ than those at the reference creek (Table 7). (4) Fertilized tall $S$. alterniflora roots and rhizomes from ingrowth cores

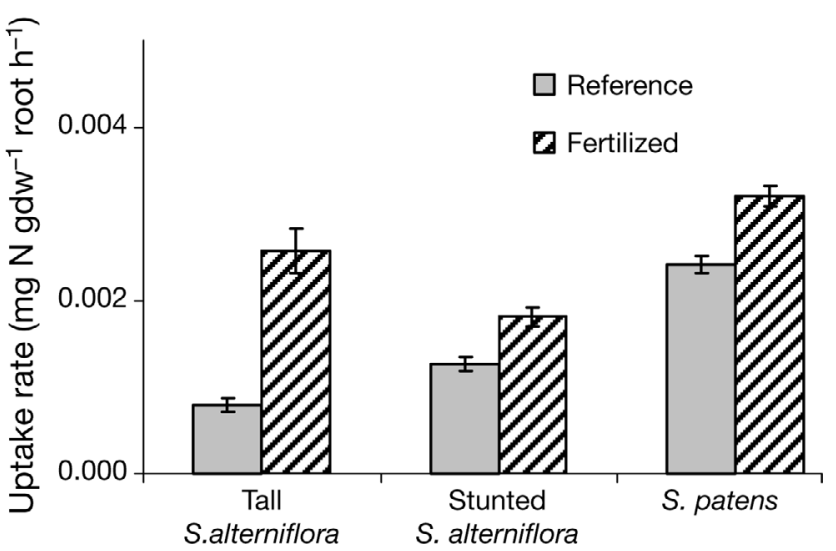

Fig. 3. Spartina spp. Rates of root $\mathrm{NO}_{3}-\mathrm{N}$ uptake required to account for ${ }^{15} \mathrm{~N}$ tracer found in leaves $17 \mathrm{~d}$ after the tracer additions were initiated. Uptake rates are corrected for hours of exposure to inundating water (flooding). Error bars are \pm SD based on $\delta^{15} \mathrm{~N}$ values of samples collected from each of the 3 permanent study plots on 9 July 2005 (new growth only) were some of the most strongly ${ }^{15} \mathrm{~N}$ enriched plant tissues that we measured (5.05 and $4.24 \%$ over baseline, respectively) while reference ingrowth core materials were only weakly enriched (1.50 and $0.21 \%$ over baseline, respectively). Tall $S$. alterniflora leaf sprouts (collected 16 November) in the reference system were only slightly more enriched than those in the fertilized system (Table 4 ).

End of season Spartina patens root $\delta^{15} \mathrm{~N}$ was slightly enriched in the reference system and not significantly different from baseline in the fertilized system, although root $\delta^{15} \mathrm{~N}$ in both systems increased by May 2006 (becoming significant in the fertilized system; Table 4). There was no difference in root percent $\mathrm{N}$ between systems (Table 7). S. patens sprouts, however, were convincingly enriched in both systems, suggesting similar allocation of recently acquired $\mathrm{N}$ to aboveground pools.

Table 7. Spartina spp. Belowground tissue $\% \mathrm{~N} \pm \mathrm{SD}$ at the end of the 2005 growing season (16 November 2005). Bold p-values indicate statistically significant differences $(\alpha<0.05)$

\begin{tabular}{|lccc|}
\hline \multicolumn{1}{|c}{$\begin{array}{c}\text { Reference } \\
\text { creek }\end{array}$} & $\begin{array}{c}\text { Fertilized } \\
\text { creek }\end{array}$ & $\begin{array}{c}\text { Significance } \\
\text { paired } t \text {-test } \\
\mathrm{p}<\end{array}$ \\
\hline \multicolumn{2}{l}{ Tall S. alternifolia } \\
Rhizome & $1.02 \pm 0.03$ & $1.40 \pm 0.21$ & $\mathbf{0 . 0 4}$ \\
Root & $1.36 \pm 0.09$ & $1.62 \pm 0.15$ & $\mathbf{0 . 0 4}$ \\
Stunted S. alternifolia & & \\
Rhizome & $0.70 \pm 0.05$ & $0.93 \pm 0.08$ & $\mathbf{0 . 0 5}$ \\
Root & $1.08 \pm 0.05$ & $1.16 \pm 0.06$ & 0.16 \\
S. patens & & & \\
Rhizome +roots & $1.16 \pm 0.08$ & $1.15 \pm 0.04$ & 0.39 \\
\hline
\end{tabular}




\section{DISCUSSION}

In this study we present quantitative evidence of several significant changes in salt marsh plant $\mathrm{N}$-dynamics with increased nutrient availability and attempt to answer the 4 questions posed in the 'Introduction'.

\section{Question 1: N uptake and uptake efficiency}

During the height of the 2005 growing season, marsh plants in the reference system $\left(\sim 4 \mathrm{\mu M} \mathrm{NO}_{3}^{-}\right.$in surface water) sequestered $24.5 \mathrm{~g} \mathrm{NO}_{3}-\mathrm{N} \mathrm{ha}^{-1} \mathrm{~d}^{-1}$ in aboveground pools, while plants in the fertilized system $\left(\sim 70 \mu \mathrm{M} \mathrm{NO}_{3}{ }^{-}\right.$in surface water) sequestered $\sim 140 \mathrm{~g}$ $\mathrm{NO}_{3}-\mathrm{N} \mathrm{ha}^{-1} \mathrm{~d}^{-1}$. When viewed from an ecosystem perspective, however, plants in the fertilized system sequestered only $\sim 2.6 \%$ of the total dissolved $\mathrm{NO}_{3}-\mathrm{N}$ entering the study area, while plants in the reference creek sequestered $\sim 16.8 \%$ of incoming $\mathrm{NO}_{3}-\mathrm{N}$, i.e. plants in the fertilized creek were less efficient at removing $\mathrm{N}$ from surface waters in a system budget context. We conclude that the $70 \mu \mathrm{M} \mathrm{NO}_{3}{ }^{-}$loading rate approaches or exceeds the point of saturation for this marsh vegetation community. This is an important finding for management of coastal nutrient loading; salt marsh vegetation becomes less effective as a pollution control at some point (threshold) between 4 and $70 \mu \mathrm{M} \mathrm{NO} \mathrm{NO}_{3}-\mathrm{N}$. Thresholds will undoubtedly vary depending on species composition, belowground $\mathrm{N}$ dynamics and years of exposure to increased nutrient loading, but this experiment provides a range of values for management targets. In unfertilized creeks $\mathrm{NO}_{3}{ }^{-}$ comprised, on average, $\sim 30 \%$ of dissolved inorganic $\mathrm{N}$ entering the study sites while $\mathrm{NH}_{4}{ }^{+}$comprised the remaining $60 \%$ (TIDE unpubl. data). Dissolved organic $\mathrm{N}$ comprises a much larger fraction of total dissolved $\mathrm{N}$ entering the marshes. However, increasing $\mathrm{NO}_{3}{ }^{-}$export from watersheds is widely documented in the eastern USA and is expected to dominate surface water $\mathrm{N}$ pollution in the future (Fenn et al. 1998). Ongoing related studies within the TIDE project are quantifying the changing role that other salt marsh pools and processes (e.g. sediments, water column N cycling) play as nutrient loading increases.

\section{Question 2: Sequestration of $\mathbf{N}$ by Spartina spp.}

The roles of the 3 plant types are relatively consistent between the reference and fertilized creeks. Tall Spartina alterniflora comprises only $\sim 2 \%$ of vegetative cover in each system, yet was responsible for 18 and $22 \%$ of the aboveground sequestration of $\mathrm{NO}_{3}$ in the reference and fertilized creeks, respectively. This large fraction is largely because tall $S$. alterniflora is inundated during more tidal cycles and for more hours per cycle than are $S$. patens or stunted $S$. alterniflora (Table 2). Additionally, tall $S$. alterniflora roots are exposed to longer periods of porewater drainage. In both systems, $S$. patens was the most abundant plant as determined by aerial coverage (52 to $60 \%$; Table 1) and was responsible for 67 and $66 \%$ of $\mathrm{NO}_{3}$ - $\mathrm{N}$ sequestration. S. patens took up the most $\mathrm{NO}_{3}{ }^{-}$per unit of aboveground biomass, especially when its low relative exposure to inundating water is considered (Table 2). Stunted $S$. alterniflora was responsible for the remaining 15 and $12 \%$ of plant $\mathrm{NO}_{3}^{-}$uptake; this species covers 20 to $27 \%$ of the study areas, but also has a relatively low aboveground biomass.

A related (within TIDE) study of vegetation growth found that plant biomass standing stocks responded positively, but subtly, to the nutrient addition. Tall Spartina alterniflora and S. patens aboveground biomass increased marginally over the reference system, but no change was detected in stunted $S$. alterniflora (Deegan et al. 2007). Increases in biomass, however, are difficult to detect against a background of large existing standing stocks, but the ${ }^{15} \mathrm{~N}$ tracer work presented here allows a closer examination of $\mathrm{N}$ fate because extremely small changes in $\mathrm{N}$ isotope composition can be accurately measured.

\section{Question 3: $\mathbf{N}$ resorption and litter quality in Spartina spp.}

Consistent changes in NRE and NRP lend strong support to the idea that a moderate (in the context of surface water pollution) increase in environmental $\mathrm{NO}_{3}{ }^{-}$ availability from 4 to $70 \mu \mathrm{M}$ in inundating water can cause significant physiological changes in marsh plants with ecosystem-scale implications. Patterns in $\mathrm{N}$ resorption conform closely to the expectation that nutrient enrichment imposed by the TIDE project should relax nutrient limitation; NRE and NRP decreased in all 3 plant types with higher $\mathrm{NO}_{3}{ }^{-}$loading. Stunted Spartina alterniflora was the least responsive to increasing $\mathrm{NO}_{3}{ }^{-}$ enrichment in terms of $\mathrm{NO}_{3}-\mathrm{N}$ uptake, yet response in leaf NRP was fairly dramatic $(57 \%$ in the reference creek and $70 \%$ in the fertilized creek; Table 6), suggesting a significant physiological shift.

Senesced leaves in the fertilized system contained $\sim 43 \%$ (tall S. alterniflora), $23 \%$ (stunted S. alterniflora) and $15 \%$ (S. patens) more N per unit mass than those in the reference system. Surface water nutrient enrichment is frequently seasonal (i.e. highest in the spring and early summer with agricultural $\mathrm{N}$ and $\mathrm{P}$ applications and higher precipitation), so increased percent $\mathrm{N}$ of senesced leaves may have a relatively large influ- 
ence in the fall and winter when surface water nutrient inputs are lower and litter contributions to near-shore waters are highest. The effects of increased leaf and root litter percent $\mathrm{N}$ on sediment dynamics are difficult to predict; microbial decay in soils and sediments is generally temperature- and C-limited, so lower C:N ratios in deposited litter may not affect decomposition. This important question is a focus of ongoing work in the larger TIDE nutrient manipulation project.

\section{Question 4: Foliar uptake and $\mathrm{N}$ allocation in plant tissues}

The N uptake rate in stunted Spartina alterniflora increased with $\mathrm{NO}_{3}{ }^{-}$loading, but its response was the weakest of the 3 Spartina types. Foliar uptake plays a minor role in seagrass $\mathrm{N}$ acquisition at low $\mathrm{N}$ loading rates (Bouma et al. 2002). The difference here between the responses of stunted and tall plants conforms to this idea. If leaves were significant sources of $\mathrm{N}$ uptake we would expect to see at least an approximately equal response in short and tall $S$. alterniflora (assuming leaf surface area: volume ratios are similar or higher in the stunted form). Instead, the weaker response in stunted $S$. alterniflora suggests that sediment chemistry continues to limit $\mathrm{N}$ uptake by roots.

Three plant tissues were notably enriched in tracer $\mathrm{N}$ at the end of the growing season: leaf sprouts, new belowground growth of tall Spartina alterniflora in the fertilized creek, and senesced leaves of the high marsh plants. Leaf sprouts, formed in August through October, were enriched relative to belowground pools in most cases. In warmer climates with longer growing seasons $S$. altenifolia sprouts can develop fully into leaves, but in the northern range, sprouts must overwinter and are frequently lost. In New England, then, leaf sprouts are a 'risky' place to invest $\mathrm{N}$; this may pay off in earlier spring growth, or it may simply be a vestige of plants adapted to warmer climates. Tracer content of new roots and rhizomes suggests a greater investment in vegetative reproduction in the high-N environment (Table 4). Lastly, ${ }^{15} \mathrm{~N}$ enrichment of senesced leaves relative to belowground pools in every case (except tall $S$. alterniflora in the fertilized creek) suggests physiological fractionation, or preferential resorption of the lighter isotope. Lack of this pattern in fertilized creek tall $S$. alterniflora is consistent with this because it resorbed almost no $\mathrm{N}$ from leaves (Table 6). There is a strong positive relationship between NRE and the difference between $\delta^{15} \mathrm{~N}$ in green and senesced leaves across all species in both systems $\left(\mathrm{r}^{2}=0.84, \mathrm{p}=0.01\right)$.

Nutrient pollution in near-shore environments will continue to increase with population growth and development in coastal areas. This study was conducted during the second year of experimental nutrient enrichment and, although difficult to predict, the effects of longer-term enrichment may include change in species compositions or increased rates of sediment decay. The responses of salt marsh vegetation to increased $\mathrm{N}$ loading quantified here provide new perspectives for understanding the limits of salt marshes as a mediator of surface water pollution, nutrient economy of salt marshes and potential interactions of nutrient loading with other ongoing environmental change.

Acknowledgements. We thank M. Hoover, A. Hasler, M. Johnson, R. Jones, C. Picard, K. Saez and C. Thurman for many long hours in the field and laboratory. We also thank 3 anonymous reviewers for their help in improving the manuscript. This work was funded by National Science Foundation Grant DEB 0213767 and OCE 9726921.

\section{LITERATURE CITED}

Aerts R (1996) Nutrient resorption from senescing leaves of perennials: Are there general patterns? J Ecol 84:597-608

Bouma TJ, Stapel J, van der Heiden J, Koutstaal B, van Soelen J, van Ijzerloo L (2002) Relative importance of macrophyte leaves for nitrogen uptake from flood water in tidal salt marshes. Mar Ecol Prog Ser 240:93-104

Bromberg KD, Bertness MD (2005) Reconstructing New England salt marsh losses using historical maps. Estuaries 28: 823-832

Cartaxana P, Catarino F (2002) Nitrogen resorption from senescing leaves of three salt marsh plant species. Plant Ecol 159:95-102

Cloern JE (2001) Our evolving conceptual model of the coastal eutrophication problem. Mar Ecol Prog Ser 210: $223-253$

Commonwealth of Massachusetts (2005) Parker River Watershed Action Plan. Available at: www.mass.gov/envir/ water/publications/WAPs/

Deegan LA, Bowen JL, Drake DC, Fleeger JW and 13 others (2007) Susceptibility of salt marshes to nutrient enrichment and predator removal. Ecol Appl 17(5):S42-S63

Fenn ME, Poth MA, Aber JD, Baron JS and 6 others (1998) Nitrogen excess in North American ecosystems: predisposing factors, ecosystem responses, and management strategies. Ecol Appl 8:706-733

Hopkinson CS (1992) A comparison of ecosystem dynamics in freshwater ecosystems. Estuaries 15:549-562

Hopkinson CS, Schubauer JP (1984) Static and dynamic aspects of nitrogen cycling in the salt marsh graminoid Spartina alterniflora. Ecology 65:961-969

Howarth RW, Billen G, Swaney D, Townsend A and 11 others (1996) Regional nitrogen budgets and riverine $N$ \& $P$ fluxes for the drainages to the North Atlantic Ocean: natural and human influences. Biogeochemistry 35:75-139

Howes BL, Howarth RW, Teal JM, Valiela I (1981) Oxidationreduction potentials in a salt marsh: spatial patterns and interactions with primary production. Limnol Oceanogr 26:350-360

Howes BL, Dacey JWH, Teal JM (1985) Annual carbon mineralization and belowground production of Spartina alterniflora in a New England salt marsh. Ecology 66:595-605 
Hurlbert SH (1984) Pseudoreplication and the design of ecological field experiments. Ecol Monogr 54:187-211

Jaworski NA, Howarth RW, Hetling LJ (1997) Atmospheric deposition of nitrogen oxides onto the landscape contributes to coastal eutrophication in the northeast United States. Environ Sci Technol 31:1995-2004

Kaplan W, Valiela I, Teal JM (1979) Denitrification in a salt marsh ecosystem. Limnol Oceanogr 24:726-734

Killingbeck KT (1996) Nutrients in senesced leaves: keys to the search for potential resorption and resorption proficiency. Ecology 77:1716-1727

Mendelssohn IA (1979) The influence of nitrogen level, form and application method of the growth response of Spartina alterniflora in North Carolina. Estuaries 2:106-112

Miao S, Carstenn S (2006) A new direction for large-scale experimental design and analysis. Front Ecol Environ 5: 227

Miller EE (2006) Experimental nutrient enrichment of a New England salt marsh: plant productivity and community composition responses. MS thesis, Connecticut College, New London, CT

Morris JT (1980) The nitrogen uptake kinetics of Spartina alterniflora in culture. Ecology 61:1114-1121

National Research Council (1994) Priorities for coastal ecosystem science. National Academy Press, Washington, DC

Niklas KJ (2004) Plant allometry: Is there a grand unifying theory? Biol Rev 79:871-889

Nixon SW (1995) Coastal marine eutrophication: a definition, social causes and future concerns. Ophelia 41:199-219

Pontius RG, Claessens L, Hopkinson C, Marzouk A, Rastetter EB, Schneider LC, Vallino J (2000) Scenarios of land-use

Editorial responsibility: Howard Browman, Storebø, Norway change and nitrogen release in the Ipswich watershed, Massachusetts, USA. 4th International Conference on Integrating GIS and Environmental Modeling (GIS/EM4) No. 165: Problems, Prospects and Research Needs. Banff, Alberta

Schubauer JP, Hopkinson CS (1984) Above and belowground emergent macrophyte production and turnover in a coastal marsh ecosystem, Georgia. Limnol Oceanogr 29: 1052-1065

Shaver GR, Melillo JM (1984) Nutrient budgets of marsh plants: efficiency concepts and relation to availability. Ecology 65:1491-1510

Smart RM (1980) Distribution and environmental control of productivity and growth form of Spartina alterniflora. In: Snecca DN, Rajpurohit KS (eds) Contributions to the ecology of halophytes. W. Junk, The Hague

Underwood A (1994) On beyond BACI: sampling designs that might reliably detect environmental disturbances. Ecol Appl 4:3-15

Valiela I (1983) Nitrogen in salt marsh ecosystems. In: Carpenter EJ, Capone DJ (eds) Nitrogen in the marine environment. Academic Press, New York, p 649-678

Valiela I, Teal JM (1979) The nitrogen budget of a salt marsh ecosystem. Nature 280:652-656

Valiela I, Teal JM,Volkmann S, Shafer D, Carpenter EJ (1978) Nutrient and particulate fluxes in a salt marsh ecosystem: tidal exchanges and inputs by precipitation and groundwater. Limnol Oceanogr 23:798-812

Verhoeven JT, Arheimer AB, Yin C, Hefting MM (2006) Regional and global concerns over wetlands and water quality. Trends Ecol Evol 21:96-103

Submitted: January 12, 2007; Accepted: July 20, 2007

Proofs received from author(s): January 18, 2007 